\title{
O gênero Strangalia Audinet-Serville no Norte e Centro-Oeste do Brasil (Coleoptera, Cerambycidae, Lepturinae)
}

\author{
Marcela L. Monné1,3 \& Miguel A. Monné2,4
}

\begin{abstract}
${ }^{1}$ Museu de Zoologia, Universidade de São Paulo, Caixa Postal 42494, 04218-970 São Paulo-SP, Brasil.
${ }^{2}$ Museu Nacional, Universidade Federal do Rio de Janeiro, Quinta da Boa Vista, São Cristovão, 20940-040 Rio de Janeiro-RJ, Brasil. ${ }^{3}$ Bolsista FAPESP.

${ }^{4}$ Pesquisador CNPq.
\end{abstract}

\begin{abstract}
The genus Strangalia Audinet-Serville in northern and central Brazil (Coleoptera, Cerambycidae, Lepturinae). The species of the genus Strangalia from northern and central Brazil are revised. Strangalia xanthomelaena sp. nov. is described from Rondônia and Mato Grosso, Brazil. Two new synonyms are proposed: Ophistomis irene Gounelle, 1911 $=$ Euryptera albicollis Pascoe, 1860; O. paraensis Bates, $1870=$ O. bivittatus Bates, 1870. Illustrations and key for identification are provided.
\end{abstract}

KEYWORDS. Cerambycidae; Lepturini; new species; Strangalia; synonyms.

RESUMO. O gênero Strangalia Audinet-Serville no Norte e Centro-Oeste do Brasil (Coleoptera, Cerambycidae, Lepturinae). As espécies do gênero Strangalia Audinet-Serville do Norte e Centro-Oeste do Brasil são revistas. Strangalia xanthomelaena sp. nov. é descrita de Rondônia e Mato Grosso, Brasil. Dois novos sinônimos são propostos: Ophistomis irene Gounelle, $1911=$ Euryptera albicollis Pascoe, 1860; O. paraensis Bates, $1870=$ O. bivittatus Bates, 1870. São fornecidas ilustrações e chave para identificação das espécies.

PALAVRAS-CHAVE. Cerambycidae; espécie nova; Lepturini; Strangalia; sinonímias.

O gênero Strangalia Audinet-Serville, 1835 apresenta 70 espécies no hemisfério ocidental sendo que destas, seis estão restritas aos Estados Unidos e 16 distribuem-se na América do Sul (Monné, 1995; Giesbert, 1997; Monné et al., 2004).

Linsley \& Chemsak (1971) redescreveram as espécies de Strangalia do México e América Central e consideraram Ophistomis Thomson, 1857 sinônimo de Strangalia. Chemsak \& Linsley (1976: 216) apresentaram chave de identificação para as espécies do México e América Central e descreveram quatro espécies. Villiers (1980:194) ao tratar da fauna das Antilhas redescreveu três espécies e forneceu chave para distinguilas. Chalumeau (1985: 148 ) descreveu uma espécie da ilha de Montserrat, elevando para quatro o número das espécies antilhanas. Giesbert (1985: 279) elaborou uma nova chave, como complemento daquela de Chemsak \& Linsley (op. cit.), possibilitando a distinção dos machos de espécies do México e América Central. Giesbert $(1986 ; 1989)$ acrescentou duas espécies ao gênero. Monné (1995: 59) listou 69 espécies no hemisfério ocidental. Giesbert (1997) descreveu sete espécies, totalizando atualmente 41 taxa para México e América Central. Monné et al. (2004) propuseram, para as espécies de Strangalia sul-americanas, a sinonímia de sete, revalidaram uma e forneceram ilustrações para seis das sete espécies que ocorrem no sudeste e sul do Brasil.

Neste trabalho as nove espécies de Strangalia que ocorrem no norte e centro-oeste do Brasil são redescritas, $S$. xanthomelaena sp. nov. é descrita de Rondônia e Mato Grosso, Brasil e são propostas as seguintes sinonímias: Ophistomis irene Gounelle, 1911 = Euryptera albicollis Pascoe, 1860; $O$. paraensis Bates, $1870=$ O. bivittatus Bates, 1870. São fornecidas chave para identificação das espécies e ilustrações.

As siglas mencionadas correspondem a: The Natural History Museum, London (BMNH); Muséum National d'Histoire Naturelle, Paris (MNHN); Museu Nacional, Universidade Federal do Rio de Janeiro, Rio de Janeiro (MNRJ); Museu de Zoologia, Universidade de São Paulo, São Paulo (MZSP); Naturhistoriska Riksmuseet, Stockholm (NHRS).

Chave para as espécies de Strangalia do Norte e CentroOeste do Brasil.

1. Élitros verdes ou azuis, com reflexos metálicos ............. 2

Élitros pretos, amarelos ou vermelhos, sem reflexos metálicos …………………………………………..... 3

2(1). Antenômeros pretos; protórax preto, revestido com densa pubescência amarelo-dourada; élitros verdes; abdome castanho-avermelhado. Guiana Francesa, Brasil (Amazonas, Rondônia, Mato Grosso) (Fig. 1) S. suavis (Melzer, 1926)

Antenômeros I - VIII pretos, IX - XI amareloesbranquiçados; protórax alaranjado, com pilosidade esparsa e preta; élitros azuis; abdome preto.Brasil (Amazonas, Rondônia, Mato Grosso) (Fig. 2) S. splendida (Aurivillius, 1920)

3(1). Dorso dos metafêmures com carena longitudinal ......... 5 Dorso dos metafêmures sem carena longitudinal ........ 4

4(3). Élitros pretos, gradualmente estreitados para os ápices em ambos os sexos; abdome preto exceto metade 
apical do último segmento, castanho. Último urosternito, nos machos, sinuoso no ápice, sem abas laterais e com pilosidade curta e esparsa. Brasil (Amazonas, Rondônia, Mato Grosso) (Fig. 3) ........... S. rubricollis (Bates, 1870)

Élitros castanho-alaranjados exceto frisos, sutural e lateral, ou quarto apical, pretos e distintamente estreitados para os ápices; abdome castanhoavermelhado exceto último segmento, preto. Último urosternito, nos machos, escavado na margem apical e com um par de projeções laterais, em forma de abas estreitas, curtas, distintamente aguçadas e com pilosidade longa e densa. Brasil (Rondônia, Mato Grosso, Goiás) (Fig. 4)

S. rubiginosa (Gounelle, 1911)

5(3). Élitros unicolores, pretos. Brasil (Pará, Rondônia, Mato Grosso, Goiás), Peru, Bolívia (Fig. 5)

S. albicollis (Pascoe, 1860)

Élitros amarelos, nitidamente bicolores ou amarelos com estreita faixa preta no décimo apical ou pretos com faixa látero-longitudinal castanho-amarelada .. 6

6(5). Élitros pretos com estreita faixa látero-longitudinal castanho-amarelada. Brasil (Pará, Rondônia, Mato Grosso, Goiás), Peru, Bolívia (Fig. 6)

S. albicollis (Pascoe, 1860)

Élitros com outro padrão de colorido

7(6). Pronoto castanho-alaranjado, sem máculas pretas ou castanho escuras. Brasil (Amazonas, Mato Grosso) (Fig. 7) S. semifulva (Bates, 1870)

Pronoto com outro padrão de colorido ... 8

8(7). Pronoto castanho-amarelado ou castanho-avermelhado com mancha preta próxima à margem anterior .......... 9

Pronoto castanho-amarelado com duas faixas láterolongitudinais pretas ou castanho-escuras 10

9(8). Pronoto castanho-avermelhado e glabro; abdome castanho-alaranjado exceto urotergitos IV-V, pretos. Brasil (Amazonas). (Fig. 8) ....

S. melanostoma (Bates, 1870)

Pronoto castanho-amarelado, com pilosidade curta, esparsa e decumbente; abdome amarelo exceto urosternito I, castanho-escuro. Guiana, Brasil (Amazonas, Rondônia, Mato Grosso) (Fig. 9) S. ochroptera (Bates, 1870)

10(8). Antenas, ambos os sexos, pretas, com anel amarelado no quinto basal dos antenômeros III-V; linhas longitudinais do pronoto dorsais, coalescentes na margem anterior; pronoto com pilosidade densa. Brasil (Rondônia, Mato Grosso) (Fig. 10) S. xanthomelaena $\mathbf{s p . ~ n o v . ~}$

Fêmeas: Antenômeros III - V amarelos, VI - XI pretos.
Machos: antenas pretas. Linhas longitudinais do pronoto látero-dorsais, não coalescentes na margem anterior; pronoto com pilosidade esparsa. Guiana, Guiana Francesa, Brasil (Amazonas, Pará) (Figs 11, 12) …….............................. S. bivittata (Bates, 1870)

\section{Strangalia suavis (Melzer, 1926)}

(Fig. 1)

Ophistomis suavis Melzer, 1926: 7; Zikán \& Wygodzinsky, 1948: 41 (tipo).

Strangalia suavis; Linsley \& Chemsak, 1971: 24

Macho. Tegumento preto; peças bucais castanho-claras a castanho-escuras; élitros verdes com brilho metálico; abdome castanho-avermelhado.

Cabeça cerca de 1/3 mais longa que larga; pilosidade densa e amarelo-dourada; pontuação fina e densa; rostro com região lisa, de aspecto triangular; sulco longitudinal raso entre os tubérculos anteníferos. Antenas, no máximo, alcançam os ápices elitrais; área porífera presente na região látero-externa dos antenômeros VI-XI; VI apenas nos 2/3 apicais; VII-XI em toda região látero-externa. Escapo, pedicelo e antenômeros III-V com pêlos curtos, densos e pretos; VI-XI com pubescência preta.

Protórax campaniforme, com sulco raso e transverso, próximo à margem anterior. Pronoto com pontos finos $\mathrm{e}$ densos; pubescência densa, decumbente e amarelo-dourada. Escutelo triangular com ápice aguçado. Élitros cerca de quatro vezes o comprimento do protórax; distintamente estreitados para os ápices e estes obliquamente truncados e com projeção espiniforme no ângulo externo; superfície densamente pontuada e com pêlos curtos, moderadamente densos e amarelo-dourados. Mesotarsômero I curto, alargado e cerca de 1,5 vezes o comprimento do seguinte. Metafêmures com carena longitudinal dorsal que alcança o ápice. Metatarsômero I alongado e cerca de 1,5 vezes o comprimento do seguinte.

Abdome estende-se além dos ápices elitrais; último urotergito com margem apical truncada; último urosternito profundamente escavado na margem apical e com um par de projeções, a cada lado, em forma de abas densamente pilosas e com ápices aguçados.

Fêmea. Antenas alcançam o terço apical dos élitros. Élitros gradualmente estreitados para o ápice. Mesotarsômero I estreito, cilíndrico e cerca de duas vezes o comprimento do seguinte. Metafêmures com carena longitudinal dorsal no 1/3 basal. Últimos urotergito e urosternito com margens apicais truncadas.

Dimensões, em mm, respectivamente macho/fêmea. Comprimento total, 12,7/9,8; comprimento do protórax, 2,0/1,6; maior largura do protórax, 1,9/1,8; comprimento do élitro, 6,6/ 6,$4 ;$ largura umeral, 2,6/2,2.

Discussão. Os élitros verdes com brilho metálico e o protórax densamente recoberto de pubescência amarelodourada, separam S. suavis de suas congêneres. S. suavis assemelha-se a $S$. splendida (Aurivillius, 1920) por 
apresentarem os élitros com brilho metálico. S. suavis difere de $S$. splendida pelos caracteres arrolados na chave.

Material examinado. GUIANA FRANCESA, Caiena, macho, fêmea, Soubirou col. (MNHN). BRASIL, Amazonas: Manicore, fêmea (MZSP, holótipo). Pará, Óbidos, macho, IX.1978, B. Silva (MNRJ). Rondônia: Vilhena, macho, fêmea, X.1988, O. Roppa, P. Magno \& J. Becker col (MNRJ). Mato Grosso: Sinop, fêmea, XI.1978, M. Alvarenga \& O. Roppa col. (MNRJ)

Strangalia splendida (Aurivillius, 1920) (Fig. 2)

Ophistomis splendida Aurivillius, 1920: 361.

Strangalia splendida; Monné, 1995: 68 (cat.).

Macho.Tegumento preto; antenômeros IX-XI amareloesbranquiçados; peças bucais, protórax, mesotórax e escutelo, alaranjados; élitros com brilho metálico azul.

Cabeça cerca de 1/3 mais longa que larga; subglabra e com pontos finos e densos; rostro, no dorso, com elevação cordiforme e lisa; sulco longitudinal profundo entre os tubérculos anteníferos. Antenas, no máximo, alcançam os ápices elitrais; região látero-externa com área porífera a partir da metade apical do antenômero VI; VII-XI em toda margem externa. Escapo, pedicelo e antenômeros III-V com pêlos curtos, densos e pretos; VI-VII com pubescência preta; IX-XI com pubescência branca.

Protórax com lados ligeiramente arredondados e com sulco transverso próximo à margem anterior. Pronoto densamente pontuado exceto em estreita faixa lisa longitudinal mediana; pilosidade curta, esparsa e preta. Escutelo triangular com ápice arredondado. Élitros cerca de quatro vezes o comprimento do protórax; distintamente estreitados para os ápices e estes obliquamente truncados e com curto espinho no ápice externo; superfície densamente pontuada e com abundantes pêlos pretos, curtos, semi-eretos e pouco contrastantes. Mesotarsômero I alargado e cerca de 1,5 vezes o comprimento do seguinte. Metafêmures com carena longitudinal dorsal que alcança o ápice. Metatarsômero I alongado e cerca do dobro do comprimento do seguinte.

Abdome estende-se além dos ápices elitrais; último urotergito com margem apical truncada; último urosternito profundamente escavado na margem apical e com um par de projeções, a cada lado, em forma de abas densamente pilosas e com ápices aguçados.

Fêmea. Antenas, no máximo, apenas ultrapassam o meio dos élitros. Élitros gradualmente estreitados para o ápice. Mesotarsômero I estreito, cilíndrico e cerca de três vezes o comprimento do seguinte. Metafêmures com carena longitudinal dorsal no $1 / 3$ basal. Último urotergito com margem apical bilobada; último urosternito deprimido na região mediana próximo à margem apical e esta truncada e sem abas laterais.

Dimensões, em mm, respectivamente macho/fêmea. Comprimento total, 16,6/15,7; comprimento do protórax, 2,3/ 2,2; maior largura do protórax, 2,1/2,8; comprimento do élitro, 10,2/12,0; largura umeral, 2,8/3,4.
Material-tipo. Examinamos diapositivo do tipo (proveniente de Tefé, Amazonas, Brasil, NHRS), realizado por Gérard Tavakilian (MNHN).

Discussão. Ver comentários em S. suavis.

Material examinado. BRASIL, Amazonas: Tefé, fêmea, XII.1961, F. M. Oliveira col. (MNRJ); Rondônia: Vilhena, fêmea, XI.1973, M. Alvarenga \& O. Roppa col. (MNRH); Mato Grosso: Colorado do Oeste, fêmea, X.1988, O. Roppa, P. Magno \& J. Becker col. (MNRJ); Diamantino (Alto Rio Arinos), macho, X.1983, B. Silva col. (MNRJ); Sinop, macho, fềmea, X.1974, M. Alvarenga \& O. Roppa col. (MNRJ); 2 machos, XI.1976, M. Alvarenga \& O. Roppa col. (MNRJ).

\section{Strangalia rubricollis (Bates, 1870)}

(Fig. 3)

Ophistomis rubricollis Bates, 1870: 312.

Strangalia rubricollis; Monné, 1995: 67 (cat.).

Macho. Tegumento preto; região posterior da cabeça, protórax e escutelo, alaranjados; metade apical do último segmento abdominal castanho.

Cabeça tão larga quanto longa; com pêlos esparsos e amarelos; pontuação fina e densa; rostro, no dorso, com elevação cordiforme e lisa; sulco longitudinal profundo entre os tubérculos anteníferos. Antenas, no máximo, alcançam o 1/ 3 ou 1/4 apical dos élitros; área porífera presente na região látero-externa dos antenômeros V-XI; V apenas no 1/3 apical e VI-XI em toda região látero-externa. Escapo, pedicelo e antenômeros III-V com pêlos curtos, densos e pretos; VI-XI com pubescência preta.

Protórax campaniforme e estreitado na margem anterior. Pronoto com pontos finos e densos e pilosidade curta, densa, decumbente e amarelo-dourada. Escutelo triangular com ápice aguçado. Élitros cerca de três vezes o comprimento do protórax; gradualmente estreitados para os ápices e estes obliquamente truncados e ápice externo aguçado; superfície com pontos finos e densos; pêlos curtos, decumbentes, densos e pretos. Mesotarsômero I curto, alargado e cerca de 1,5 vezes o comprimento do seguinte. Metafêmures sem carena longitudinal dorsal. Metatarsômero I alongado, estreito e cerca do dobro do comprimento do seguinte.

Abdome não se estende além dos ápices elitrais; últimos, urotergito e urosternito, com margens apicais sinuosas e sem abas.

Fêmea. Antenas apenas ultrapassam o meio dos élitros. Mesotarsômero I estreito, cilíndrico e cerca do dobro do comprimento do seguinte. Último urotergito ligeiramente sinuoso na margem apical; último urosternito deprimido no meio e com abas laterais curtas e aguçadas.

Dimensões, em mm, respectivamente macho/fêmea. Comprimento total,10,1-11,0/11,0-12,0 ;comprimento do protórax, 2,0-2,3/2,3-2,8; maior largura do protórax, 2,1-2,2/2,63,0 ; comprimento do élitro, 6,0-6,5/6,5-8,3; largura umeral, 2,52,9/3,0-4,0.

Discussão. Apenas S. rubricollis e S. rubiginosa Gounelle, 1911 não apresentam carena no dorso dos metafêmures e diferem pelos caracteres descritos na chave. 
Material examinado. BRASIL, Amazonas: Ega [Tefé], macho, Bates col. (MNHN, holótipo); Fonte Boa, 2 fêmeas, X.1975, F. M. Oliveira col. (MNRJ); Jutai (BR 319, km 369), fêmea, IX.1978, J. Becker \& B. Silva col. (MNRJ); Rondônia: Ouro Preto d'Oeste, fêmea, VIII.1980, B. Silva col. (MNRJ); fêmea, X.1988, O Roppa, P. Magno \& J. Becker col. (MNRJ); Vilhena, macho, X.1986, O. Roppa, P. Magno \& J. Becker col. (MNRJ); macho, XI.1987, O. Roppa \& P. Magno col. (MNRJ); 3 machos, X.1988, O. Roppa, P. Magno \& J. Becker col. (MNRJ); macho, XI.1990, O. Roppa \& J. Becker col. (MNRJ). Mato Grosso: Barra do Bugres, 36 machos, 4 fêmeas, X-XI.1984, O. Roppa \& B. Silva col. (MNRJ); Sinop, macho, X.1974, M. Alvarenga \& O. Roppa col. (MNRJ). PERU, Junin: Satipo, fêmea, X.1943 (MNRJ).

\section{Strangalia rubiginosa (Gounelle, 1911)} (Fig. 4)

Ophistomis rubiginosa Gounelle, 1911: 105; Boppe, 1921: 104, pr. 8, fig. 8 .

Strangalia rubiginosa; Linsley \& Chemsak, 1971: 24.

Macho. Cabeça, antenas, margem anterior do pronoto, metade apical dos metafêmures, metatíbias, metatarsos, quarto apical dos élitros e último segmento abdominal, pretos; pronoto e segmentos abdominais I-IV, castanho-avermelhados; peças bucais, prosterno, mesosterno e metasterno, pernas anteriores e medianas, metade basal dos metafêmures e élitros, castanhoalaranjados.

Cabeça cerca de 1/3 mais longa que larga; pilosidade esparsa e esbranquiçada; pontuação fina e densa; rostro, no dorso, com elevação cordiforme e lisa; sulco longitudinal profundo entre os tubérculos anteníferos. Antenas, no máximo, alcançam o 1/5 apical dos élitros; área porífera presente na região látero-externa dos antenômeros VI-XI; no VI apenas no 1/3 apical e em toda região látero-externa dos VII-XI. Escapo, pedicelo e antenômeros III-VI com pêlos curtos, densos e pretos; VII-XI com pubescência preta.

Protórax campaniforme e com sulco profundo e transverso, próximo à margem anterior. Pronoto com pontos finos e esparsos e pilosidade curta, esparsa, decumbente e preta. Escutelo triangular com ápice aguçado. Élitros cerca de quatro vezes o comprimento do protórax; distintamente estreitados para os ápices e estes obliquamente truncados e com projeção espiniforme no ápice externo; superfície com pontos finos e moderadamente densos e pêlos curtos, decumbentes, moderadamente densos e amarelados. Mesotarsômero I curto, estreito e cerca de 1,5 vezes o comprimento do seguinte. Metafêmures sem carena longitudinal dorsal. Metatarsômero I alongado, estreito e cerca de 1,5 vezes o comprimento do seguinte.

Abdome estende-se além dos ápices elitrais; último urotergito com margem apical sinuosa; último urosternito nos machos, escavado na margem apical e com um par de projeções laterais, em forma de abas estreitas,curtas, distintamente aguçadas e com pilosidade longa e densa.

Fêmea. Élitros pretos no $1 / 3$ apical. Antenas alcançam o $1 / 4$ apical dos élitros. Mesotarsômero I estreito, cilíndrico e cerca do dobro do comprimento do seguinte. Último urotergito bilobado; último urosternito deprimido no meio, com margem apical truncada e com abas laterais curtas e aguçadas.
Dimensões, em mm, respectivamente macho/fêmea. Comprimento total, 12,8/12,0; comprimento do protórax, 1,8/ 2,$0 ;$ maior largura do protórax, 1,9/2,1; comprimento do élitro, 8,2/7,7; largura umeral, 2,5/2,6.

Discussão. Os élitros alongados e estreitos, de coloração predominantemente castanho-alaranjada e as pernas anteriores e médias uniformemente castanho-alaranjadas, permitem o reconhecimento de $S$. rubiginosa. Ver discussão em $S$. rubricollis.

Material examinado. BRASIL. Rondônia: Vilhena, macho, XI.1987, O. Roppa \& P. Magno col. (MNRJ). Mato Grosso: Barra do Bugres, 2 machos, X.1984, B. Silva col. (MNRJ). Goiás: Jataí, 2 machos, 2 fêmeas, XII.1897-I.1898, C. Pujol col. (MNHN, cótipos).

\section{Strangalia albicollis (Pascoe, 1860)}

(Figs. 5, 6)

Euryptera albicollis Pascoe, 1860: 63.

Ophistomis albicollis; Bates, 1870: 313.

Strangalia albicollis; Monné, 1995: 60 (cat.).

Ophistomis irene Gounelle, 1911: 103, Syn. nov.

Strangalia irene; Linsley \& Chemsak, 1971: 24.

Macho. Tegumento predominantemente preto a castanho escuro;cabeça amarela, com linha mediana frontal preta; antenas pretas exceto faixa transversa basal dos antenômeros III-V ou VII; protórax vermelho ou preto com os lados amarelados; élitros com faixa látero-longitudinal castanhoamarelada na metade ou terço basal ou totalmente pretos; fêmures pretos ou amarelos com faixa castanho-escura lateral externa; metatíbias pretas ou parciamente amareladas.

Cabeça cerca de 1/3 mais longa que larga; pilosidade moderadamente densa e amarela; pontuação fina e densa; rostro, no dorso, com elevação cordiforme e lisa; sulco longitudinal profundo entre os tubérculos anteníferos. Antenas, no máximo, alcançam o1/4 apical dos élitros; área porífera presente na margem látero-externa dos antenômeros V-XI; no V apenas no 1/3 apical; VI-XI em toda margem láteroexterna. Escapo, pedicelo e antenômeros III-V com pêlos curtos, densos e pretos; VI-XI com pubescência preta.

Protórax campaniforme e com sulco profundo e transverso, próximo à margem anterior. Pronoto com pontos finos e densos e pilosidade curta, densa, decumbente e castanho-escura no disco e amarelada aos lados. Escutelo triangular com ápice arredondada. Élitros cerca de quatro vezes o comprimento do protórax; gradualmente estreitados para os ápices e estes obliquamente truncados e com projeção espiniforme no ápice externo; superfície com pontos finos e densos e pêlos curtos, decumbentes, moderadamente densos e amarelados. Mesotarsômero I curto, alargado e cerca de 1,5 vezes o comprimento do seguinte. Metafêmures com carena longitudinal dorsal que alcança o ápice. Metatarsômero I alongado, estreito e cerca do dobro do comprimento do seguinte.

Abdome estende-se além dos ápices elitrais; último urotergito com margem apical sinuosa; último urosternito profundamente escavado na margem apical e com um par de 

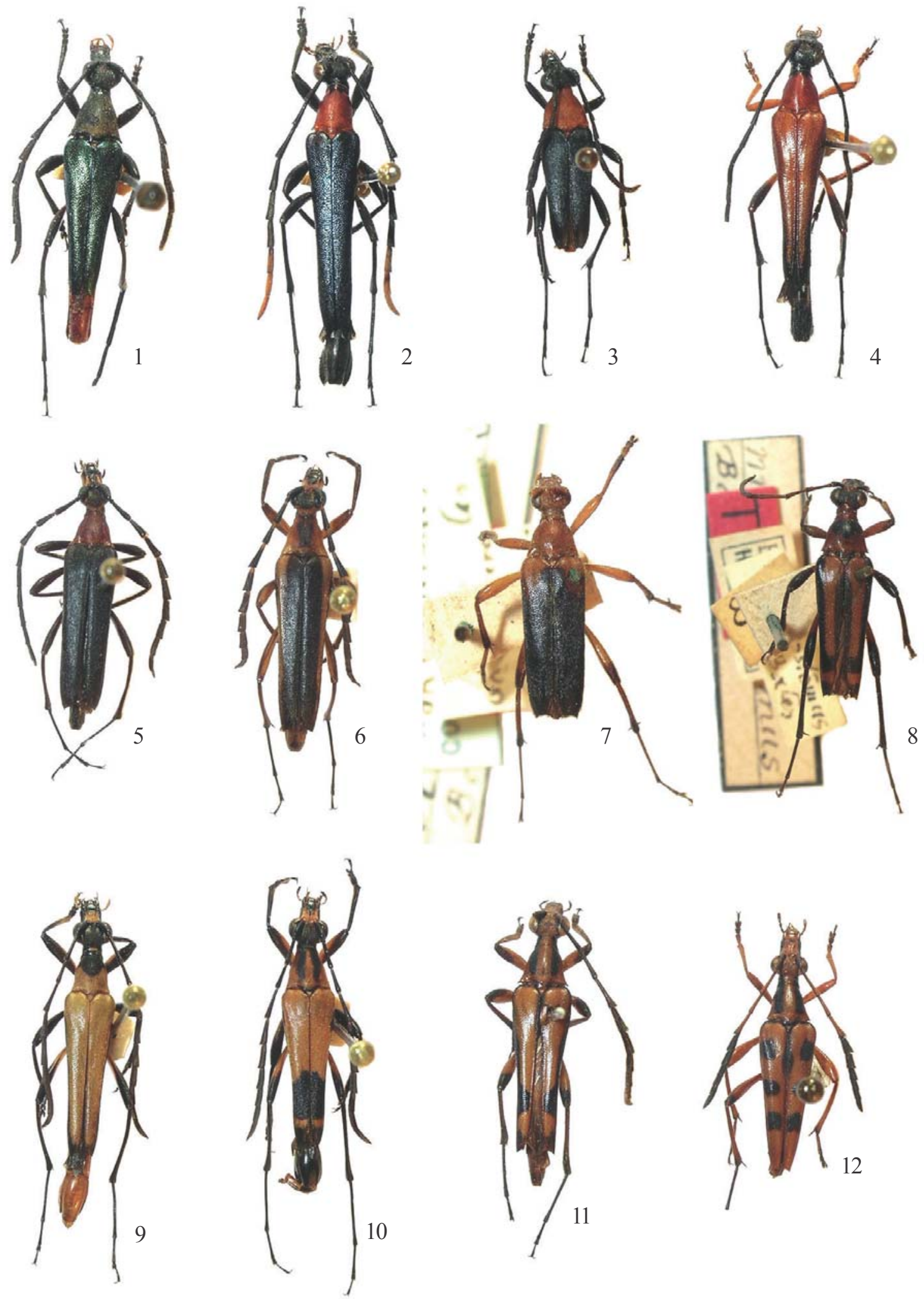

Figs. 1-12. 1-6, 1, Strangalia suavis (Melzer, 1926), macho, 12,7 mm; 2, S. splendida (Aurivillius, 1920), macho, 18,2 mm; 3, S. rubricollis (Bates, 1870), macho, 10,9 mm; 4, S. rubiginosa (Gounelle, 1911), macho, 14,8 mm; 5, 6, S. albicollis (Pascoe, 1860). 5, macho, 12,7 mm; 6, macho, 12,3 mm. 7-12, 7, Strangalia semifulva (Bates, 1870), holótipo fêmea, comprimento 10,0 mm; 8, S. melanostoma (Bates, 1870), holótipo fêmea, 12,2 mm; 9, S. ochroptera (Bates, 1870), macho, 13,2 mm; 10, S. xanthomelaena sp. nov., holótipo macho, comprimento 11,0 $\mathrm{mm} ; 11,12$, S. bivittata (Bates, 1870). 11, macho, 13,3 mm; 12, fêmea, 12,5 mm. 
projeções, a cada lado, em forma de abas estreitas, curtas, distintamente aguçadas e com pilosidade esparsa.

Fêmea. Antenas apenas ultrapassam o meio dos élitros. Mesotarsômero I estreito, cilíndrico e cerca do dobro do comprimento do seguinte. Metafêmures com carena longitudinal dorsal no $1 / 3$ basal. Último urotergito ligeiramente sinuoso na margem apical; último urosternito deprimido no meio e com abas laterais curtas e aguçadas.

Dimensões, em mm, respectivamente macho/fêmea. Comprimento total, 12,8/12,2; comprimento do protórax, 2,1/ 2,0; maior largura do protórax, 2,2/2,7; comprimento do élitro, $8,7 / 9,8$; largura umeral, 2,7/3,2

Discussão. O exame do diapositivo do tipo de S. albicollis (BMNH), dos cótipos de S. irene (MNHN) e do material examinado permitiu propor a presente sinonímia. Observouse que a espécie é muito variável na coloração, apresentando protórax vermelho ou preto e os élitros podem ser pretos a castanho-alaranjados, com ou sem faixa amarelada láterolongitudinal.

Material-tipo. Examinamos diapositivo do tipo de $S$. albicollis (proveniente de Pará, Brasil, BMNH) realizado por G. Tavakilian (MNHN) e dois cótipos, macho e fêmea, de Ophistomis irene (MNHN).

Material examinado. BRASIL, Pará: Óbidos, fêmea, XII.1964, A. Maller col. (MNRJ). Rondônia: Porto Velho, macho, fêmea, 6.X.1978, B. Silva \& J. Becker col. (MNRJ); Vilhena, fêmea, XI.1960, M. Alvarenga col. (MNRJ); 3 machos, XI.1987, O. Roppa \& P. Magno col. (MNRJ); 4 machos, 4 fêmeas, O. Roppa, P. Magno \& J. Becker col. (MNRJ); fêmea, X.1990, O. Roppa \& J. Becker col. (MNRJ). Mato Grosso: Barra do Bugres, macho, XI.1983, B. Silva, O. Roppa \& J. Becker col. (MNRJ); 20 machos, 6 fêmeas, X.1984, O. Roppa \& B. Silva col (MNRJ); Colorado do Oeste, fêmea, X.1988, O. Roppa, P. Magno \& J. Becker col. (MNRJ); Rio Verde, macho, X.1963, A. Maller col. (MNRJ); Sinop, 2 machos, 2 fêmeas, X.1974, M. Alvarenga \& O. Roppa col. (MNRJ); 2 fêmeas, X.1975, M. Alvarenga \& O. Roppa col. (MNRJ); Vera, fêmea, X.1973, M. Alvarenga \& O. Roppa col. Goiás: Jataí, macho, fêmea, XII.1897-I.1898, C. Pujol col. (MNHN, cótipos de Ophistomis irene); macho, XI.1972, F. M. Oliveira col. (MNRJ); Serranopolis, 9 machos, 5 fêmeas, XI.1972, F. M. Oliveira col. (MNRJ). PERU, Loreto: Pucallpa, macho, 28.IX.1961, J. Schunke col. (MNRJ). BOLIVIA, Santa Cruz: Quatro Ojos, fêmea, XI.1913, J. Steinbach Col. (CMNH).

\section{Strangalia semifulva (Bates, 1870)}

(Fig. 7)

Ophistomis semifulva Bates, 1870: 313.

Strangalia semifulva; Monné, 1995: 67 (cat.).

Fêmea. Tegumento castanho-alaranjado; ápices das mandíbulas pretos; antenas castanho-claras; élitros pretos exceto faixa transversal na base, castanho-avermelhado; pernas castanho-claras exceto metade apical das protíbias e mesotíbias, terço apical das metatíbias e 1/4 apical dos metafêmures, pretos.

Cabeça cerca de 1/3 mais longa que larga; pilosidade moderadamente densa e amarela; pontuação fina e densa; rostro, no dorso, com elevação cordiforme e lisa; sulco longitudinal profundo entre os tubérculos anteníferos. Antenas alcançam o meio dos élitros; área porífera presente na região látero-externa dos antenômeros V-XI; V no 1/3 apical; VI-XI em toda região látero-externa. Escapo, pedicelo e antenômeros III-IV com pêlos curtos, densos e pretos; V-XI com pubescência amarelo-dourada.

Protórax campaniforme e com sulco profundo e transverso, próximo à margem anterior. Pronoto com pontos finos e densos exceto estreita faixa glabra e lisa longitudinal mediana; pilosidade curta, densa, decumbente e dourada. Escutelo triangular com ápice arredondado. Élitros cerca de três vezes o comprimento do protórax; gradualmente estreitados para os ápices e estes obliquamente truncados e biespinhosos, sendo o externo mais longo que o sutural; superfície com pontos finos e densos; pêlos curtos, decumbentes, moderadamente densos e pretos exceto ao longo da faixa transversal na região anterior, dourados. Mesotarsômero I estreito, cilíndrico e cerca do dobro do comprimento do seguinte. Metafêmures com carena longitudinal dorsal no $1 / 3$ basal. Metatarsômero I alongado, estreito e cerca do dobro do comprimento do seguinte.

Último urotergito ligeiramente sinuoso na margem apical; último urosternito deprimido no meio e com abas laterais curtas e aguçadas.

Dimensões, em mm, fêmea. Comprimento total, 10,0; comprimento do protórax, 1,5; maior largura do protórax, 2,0; comprimento do élitro, 7,0; largura umeral, 2,8.

Variabilidade. Os élitros podem ser castanho-avermelhados com faixa sutural, exceto no $1 / 4$ basal, e ápices, pretos. Élitros com pilosidade uniformemente dourada.

Discussão. Entre as espécies que apresentam o pronoto uniformemente avermelhado ou alaranjado $S$. semifulva difere de $S$. rubiginosa e $S$. rubricollis por apresentar metafêmures com carena no dorso. Difere de $S$. splendida pelos élitros sem brilho metálico e de S. albicollis pelos antenômeros unicolores e élitros com faixa transversal na base castanho-avermelhada.

Material examinado. BRASIL. Amazonas: Ega [Tefé], fêmea, Bates col. (MNHN, holótipo de Ophistomis semifulva, "on flowers within Odontocera and Rhinotragini”). Mato Grosso: Sinop, fêmea, X.1976, M. Alvarenga \& O. Roppa col. (MNRJ).

\section{Strangalia melanostoma (Bates, 1870)}

$$
\text { (Fig. 8) }
$$

Ophistomis melanostoma Bates, 1870: 312.

Strangalia melanostoma; Monné, 1995: 66 (cat.).

Fêmea. Cabeça castanho-alaranjada exceto região anterior e vértice, pretos. Antenas castanho-avermelhadas e escurecidas para o ápice. Região ventral castanho-alaranjada exceto urotergitos IV-V, pretos. Pronoto castanho-avermelhado com mancha preta ântero-mediana que não alcança a margem anterior. Escutelo preto. Élitros castanho-avermelhados com faixa sutural, lateral, transversal no terço apical e ápices, pretos. Pernas anteriores castanho-avermelhadas, exceto mancha apical no dorso das protíbias e profêmures. Pernas médias e posteriores pretas com metade basal dos meso- e metafêmures amarelados. 
Cabeça cerca de 1/3 mais longa que larga; pilosidade esparsa e amarelada; pontuação fina e densa; rostro, no dorso, com elevação cordiforme e lisa; sulco longitudinal profundo entre os tubérculos anteníferos. Antenas alcançam o meio dos élitros; pilosidade curta, densa e preta; área porífera presente em toda região látero-externa dos antenômeros VII-XI.

Protórax campaniforme e com sulco profundo e transverso, próximo à margem anterior. Pronoto glabro e com pontos finos e densos. Escutelo triangular com ápice arredondado. Élitros cerca de quatro vezes o comprimento do protórax; gradualmente estreitados para os ápices e estes obliquamente truncados e biespinhosos, espinho lateral com o dobro do comprimento do sutural; superfície com pontos setígeros e densos e pêlos curtos, decumbentes, moderadamente densos e pretos ou castanhos, dependendo da coloração do tegumento. Mesotarsômero I curto, alargado e cerca de 3 vezes o comprimento do seguinte. Metafêmures com carena longitudinal dorsal pouco evidente, restrita ao terço basal. Metatarsômero I alongado, estreito e cerca de 1,5 vezes o comprimento do seguinte.

Último urotergito com margem apical distintamente bilobada; último urosternito deprimido no meio, com margem apical emarginada e sem abas laterais.

Dimensões, em mm,fêmea. Comprimento total, 12,2; comprimento do protórax, 2,1; maior largura do protórax, 2,6; comprimento do élitro, 8,0; largura umeral, 3,1.

Material examinado. BRASIL. Amazonas: Ega [Tefé], fêmea, Bates col. (holótipo, MNHN).

Discussão. Bates (1870: 312) ao afirmar na descrição de $O$. melanostoma "Possibly the female of Oph. ochropterus", não conhecia a fêmea desta última espécie já que, de maneira geral, apresenta o mesmo padrão de colorido do macho (Fig. 9). Strangalia melanostoma assemelha-se a $S$. bivittata pelo colorido geral do tegumento e difere, além dos carateres citados na chave, pelo pronoto com sulco profundo próximo à margem anterior e o último urotergito com a margem apical bilobada. Em S. bivittata o pronoto apresenta sulco raso e o último urotergito tem a margem apical truncada.

\section{Strangalia ochroptera (Bates, 1870)} (Fig. 9)

Ophistomis ochroptera Bates, 1870: 312.

Strangalia ochroptera; Linsley \& Chemsak, 1971: 24.

Macho. Tegumento de maneira geral castanho-amarelado; antenas e cabeça pretas exceto região dorsal anterior e região dorsal posterior mediana, castanho-amareladas; pronoto com mancha preta na metade anterior; ápice dos élitros pretos; pernas pretas exceto terço basal dos fêmures e terço apical das protíbias castanho-amarelados; urosternito I, castanhoescuro.

Cabeça cerca de 1/3 mais longa que larga; pilosidade esparsa e amarelada; pontuação fina e densa; rostro, no dorso, com elevação cordiforme e lisa; sulco longitudinal profundo entre os tubérculos anteníferos. Antenas, no máximo, alcançam os ápices elitrais; área porífera presente na região látero-externa dos antenômeros VI-XI; no VI apenas na metade apical e nos VII-XI, em toda região látero-externa. Escapo, pedicelo e antenômeros III-VI com pêlos curtos, densos e pretos; VII-XI com pubescência preta.

Protórax campaniforme e com sulco profundo e transverso, próximo à margem anterior. Pronoto com pontos finos e densos e pilosidade curta, esparsa, decumbente e amarelada exceto na mancha preta onde a pilosidade acompanha a cor do tegumento, preta. Escutelo triangular com ápice arredondado. Élitros cerca de quatro vezes o comprimento do protórax; distintamente estreitados para os ápices e estes obliquamente truncados e aguçados; superfície com pontos finos e densos e pêlos curtos, decumbentes, moderadamente densos e amarelados. Mesotarsômero I curto, alargado e cerca de 1,5 vezes o comprimento do seguinte. Metafêmures com carena longitudinal dorsal que alcança o ápice. Metatarsômero I alongado, estreito e cerca de 1,5 vezes o comprimento do seguinte.

Abdome estende-se além dos ápices elitrais; último urotergito com margem apical sinuosa; último urosternito profundamente escavado na margem apical e com um par de projeções, a cada lado, em forma de abas estreitas, alongadas e com ápices arredondados e pilosidade longa e densa.

Fêmea. Élitros pretos no 1/3 apical. Antenas alcançam o 1/ 3 apical dos élitros. Mesotarsômero I estreito, cilíndrico e cerca de 2,5 vezes o comprimento do seguinte. Último urotergito com margem apical bilobada; último urosternito deprimido no meio, com margem apical truncada e sem abas laterais.

Dimensões, em mm, respectivamente macho/fêmea. Comprimento total, 13,2/13,4; comprimento do protórax, 2,1/ 2,3 ; maior largura do protórax, 1,9/2,4; comprimento do élitro, 8,0/8,3; largura umeral, 2,5/2,9.

Discussão. A coloração predominantemente amarelada em ambos sexos e o urosternito I castanho-escuro, permite o reconhecimento de $S$. ochroptera.

Material examinado. GUIANA. Essequibo River (Firsts Falls), fêmea, 4.X.1929, Oxford University Expedition col. (BMNH). BRASIL. Amazonas: Ega [Tefé], macho, Bates col. (holótipo, MNHN); Fonte Boa, fêmea, X.1975, F. M. Oliveira col. (MNRJ); São Paulo de Olivença, macho, III.1883, M. de Mathan col. (MNHN); Tocantins, fêmea, VIIIX.1880, M. de Mathan col. (MNHN). Mato Grosso: Sinop, fêmea, X. 1974, M. Alvarenga \& O. Roppa col. (MNRJ).

\section{Strangalia xanthomelaena sp. nov.}

(Fig. 10)

Macho. Tegumento de maneira geral castanho-amarelado; cabeça preta exceto região ventral e fronte, amarelas; antenas pretas; pronoto amarelo, com duas faixas pretas longitudinais; élitros amarelados, úmeros e metade distal pretos, interrompida por faixa transversa amarela ante-apical; fêmures amarelos com a metade distal castanho-escuro a preto.

Cabeça cerca de 1/3 mais longa que larga; pilosidade esparsa e amarelada; pontuação fina e densa; rostro, no dorso, 
com elevação cordiforme e lisa; sulco longitudinal profundo entre os tubérculos anteníferos. Antenas, no máximo, alcançam os ápices elitrais; área porífera presente na região látero-externa dos antenômeros VI-XI; no VI apenas na metade apical e nos VII-XI, em toda região látero-externa. Escapo, pedicelo e antenômeros III-VI com pêlos curtos, densos e pretos; VII-XI com pubescência preta.

Protórax campaniforme e com sulco profundo e transverso, próximo à margem anterior. Pronoto com pontos finos e densos e pilosidade curta, densa, decumbente e amarelada exceto na mancha preta onde a pilosidade acompanha a coloração do tegumento preto. Escutelo triangular com ápice arredondado. Élitros cerca de quatro vezes o comprimento do protórax; distintamente estreitados para os ápices e estes obliquamente truncados e aguçados; superfície com pontos finos e densos e pêlos curtos, decumbentes, moderadamente densos e amarelados. Mesotarsômero I curto, alargado e cerca de 1,5 vezes o comprimento do seguinte. Metafêmures com carena longitudinal dorsal que alcança o ápice. Metatarsômero I alongado, estreito e cerca de 1,5 vezes o comprimento do seguinte.

Abdome estende-se além dos ápices elitrais; último urotergito com margem apical sinuosa; último urosternito profundamente escavado na margem apical e com um par de projeções, a cada lado, em forma de abas estreitas, alongadas e com ápices arredondados e pilosidade longa e densa.

Fêmea. Antenas alcançam o $1 / 3$ apical dos élitros. Mesotarsômero I estreito, cilíndrico e cerca de 2,5 vezes o comprimento do seguinte. Último urotergito com margem apical bilobada; último urosternito deprimido no meio, com margem apical truncada e sem abas laterais.

Dimensões, em mm, respectivamente macho/fêmea. Comprimento total, 11,0-13,3/10,0-14,0; comprimento do protórax, 2,0-2,5/1,8-2,0; maior largura do protórax, 2,0-2,4/2,02,5; comprimento do élitro, 7,0-8,2/7,0-9,2; largura umeral, 2,23,0/2,3-3,0.

Discussão. S. xanthomelaena sp. nov. assemelha-se a $S$. bivittata (Bates, 1870) pelo padrão de colorido e difere, além dos caracteres arrolados na chave, pela metade anterior dos élitros dos machos sem linha preta sutural ou láterolongitudinal; em S. bivittata, uma linha preta acompanha a metade anterior da sutura e linha escura látero-longitudinal atinge os dois terços anteriores dos élitros. As fêmeas de $S$. xanthomelaena sp. nov. mostram idêntico padrão cromático que os machos; em S. bivittata os élitros das fêmeas, predominantemente castanho-amarelados, estão ornados com três maculas arredondadas pretas ou castanho-escuras e a metade anterior da sutura aparece enegrecida.

Material-tipo. Holótipo macho. BRASIL, Rondônia: Vilhena, X.1988, O. Roppa, P. Magno \& J. Becker col. (MNRJ). Parátipos: BRASIL, Rondônia: Vilhena, 9 machos, fêmea, XI.1987, O. Roppa \& P.Magno col. (MNRJ); 19 machos, 8 fêmeas, X.1988. O. Roppa, P. Magno \& J. Becker col. (MNRJ). Mato Grosso: fêmea (MNHN). Barra do Bugres, macho, XI.1983, B. Silva, O. Roppa \& J. Becker col. (MNRJ); macho, XII.1983, B. Silva col. (MNRJ); 41 machos, 26 fêmeas, X.1984, O. Roppa \& B. Silva col. (MNRJ, 2 machos e 2 fêmeas, MZSP). Sinop,
2 machos, 3 fêmeas, X.1974, Alvarenga \& Roppa col. (MNRJ); fêmea, X.1975, Alvarenga \& Roppa col. (MNRJ).

\section{Strangalia bivittata (Bates, 1870)}

(Figs. 11, 12)

Ophistomis bivittatus Bates, 1870: 311; Chemsak, 1967: 82 (lect.). Strangalia bivittata; Linsley \& Chemsak, 1971: 24; Tavakilian in Hequet, 1996: pr. 13, fig. 7

Ophistomis paraensis Bates, 1870: 311, Syn. nov.

Strangalia paraensis; Monné, 1995: 67 (cat.).

Macho. Tegumento de maneira geral castanho-alaranjado. Lados da cabeça, antenas, duas faixas longitudinais não coalescentes no pronoto, frisos suturais e laterais e duas faixas transversais no terço apical dos élitros, ápices dorsais dos fêmures, tíbias e tarsos, último segmento abdominal, pretos.

Cabeça cerca de 1/3 mais longa que larga; pilosidade esparsa e amarelada; pontuação fina e densa; rostro, no dorso, com elevação cordiforme e lisa; sulco longitudinal raso entre os tubérculos anteníferos. Antenas, no máximo, alcançam os ápices elitrais; área porífera presente em toda região láteroexterna dos antenômeros VI-XI. Escapo, pedicelo e antenômeros III-V com pêlos curtos, densos e pretos; VI-XI com pubescência preta.

Protórax campaniforme e com sulco raso e transverso, próximo à margem anterior. Pronoto com pontos finos e densos e pilosidade curta, esparsa, decumbente e amarelada exceto na mancha preta onde a pilosidade é preta. Escutelo triangular com ápice arredondado. Élitros cerca de 3,5 vezes o comprimento do protórax; distintamente estreitados para os ápices e estes obliquamente truncados e aguçados; superfície com pontos finos e densos e pêlos curtos, decumbentes, moderadamente densos e amarelados ou pretos, acompanhando a coloração do tegumento. Mesotarsômero I curto, alargado e cerca de 1,5 vezes o comprimento do seguinte. Metafêmures com carena longitudinal dorsal que alcança o terço apical. Metatarsômero I alongado, estreito e cerca do dobro do comprimento do seguinte.

Abdome estende-se além dos ápices elitrais; último urotergito com margem apical ligeiramente escavada; último urosternito profundamente escavado na margem apical e com um par de projeções a cada lado, em forma de abas largas, alongadas, com ápices arredondados e projeção espiniforme mediana e pilosidade longa e densa.

Fêmea. Antenas alcançam o 1/3 apical dos élitros. Élitros predominantemente amarelados, com a metade anterior da sutura e três manchas pretas arredondadas. Mesotarsômero I estreito, cilíndrico e cerca de 2,5 vezes o comprimento do seguinte. Último urotergito com margem apical truncada; último urosternito deprimido no meio, com margem apical truncada e sem abas laterais.

Variabilidade. Escapo e pedicelo podem ser castanhos e antenômeros III-V castanho-alaranjados. Na fêmea, as manchas pretas ante-apicais dos élitros podem coalescer, formando faixa transversal. Pernas castanho-avermelhadas com ápices dos fêmures, tíbias e tarsos, pretos. 
Dimensões, em mm, respectivamente macho/fêmea. Comprimento total, 13,7/12,4; comprimento do protórax, 2,6/ 2,1; maior largura do protórax, 2,6/2,7; comprimento do élitro, 8,4/7,7; largura umeral, 3,1/2,9.

Discussão. Bates (1870: 311) iniciou a descrição de Ophistomis paraensis afirmando que era uma espécie muito próxima de $O$. bivittatus, distinguindo-se apenas pela coloração mais acastanhada. O exame do holótipo de Ophistomis paraensis, do lectótipo de $O$. bivittata e de mais treze exemplares nos permitiu observar a variabilidade da coloração e propor a sinonímia acima. Ver comentários em $S$. melanostoma e $S$. xanthomelaena.

Material examinado. GUIANA, Essequibo River (Moraballi Creek) 2 fêmeas, IV.1929, Oxford University Expedition col. (BMNH). BRASIL, Amazonas: "Amazons", macho, fêmea (BMNH); Ega [Tefé], macho, Bates col. (lectótipo de Ophistomis bivittata, MNHN); fêmea, Bates col (BMNH); Manaus, fêmea, VIII.1947, O. Roppa col. (MNRJ);Vila Nova [Parintins], 2 machos, fêmea, (BMNH). Pará: macho, Bates col. (holótipo de Ophistomis paraensis, MNHN); fêmea (BMNH)

Agradecimentos. Ao Gérard Luc Tavakilian (MNHN) pelo empréstimo de material e envio de diapositivos dos tipos. Ao Dr. José Ricardo M. Mermudes pelo auxílio na execução das fotografias. À FAPESP pela concessão da bolsa de estudos (Proc. 03/00511-3).

\section{REFERÊNCIAS}

Aurivillius, C. 1920. Neue oder wenig bekannte Coleoptera Longicornia. 17. Arkiv för Zoologi 13: 361-403.

Bates, H. W. 1870. Contribution to an insect fauna of the Amazon Valley (Coleoptera: Cerambycidae). The Transactions of the Entomological Society of London 1870: 243-335.

Boppe, P. L. 1921. Genera Insectorum, Fam. Cerambycidae: subfam. Disteniinae-Lepturinae. Bruxelles, P. Wytsman, 178: 1-119.

Chalumeau, F. 1985. Quelques Cerambycidae (Coleoptera) mimetiques des Petites Antilles et description d'une espèce nouvelle. L'Entomologiste 41: 147-152.

Chemsak, J. A. 1967. Lectotype designations of Cerambycidae in the Muséum d'Histoire Naturelle, Paris. Journal of the Kansas
Entomological Society 40: 81-83.

Chemsak, J. A. \& Linsley, E. G. 1976. A review of the Mexican and Central American species of Strangalia Audinet-Serville (Coleoptera: Cerambycidae). Journal of the New York Entomological Society 84: 216-232.

Giesbert, E. F. 1985. Additional species in the genus Strangalia (Coleoptera, Cerambycidae) in Central America, with a revised key to males. The Pan-Pacific Entomologist 61: 273-287, 4 figs.

Giesbert, E. F. 1986. A new species of Strangalia (Coleoptera: Cerambycidae) from Western Mexico. The Pan-Pacific Entomologist 62: 140-143.

Giesbert, E. F. 1989. A new species of Strangalia Audinet-Serville (Coleoptera: Cerambycidae) from Monteverde, Costa Rica. The Pan-Pacific Entomologist 65: 463-467.

Giesbert, E. F. 1997. Further studies in the Lepturini (Coleoptera, Cerambycidae, Lepturinae) of Central America. Occasional Papers of the Consortium Coleopterorum 1: 17-42.

Gounelle, E. 1911. Liste des cérambycides de la région de Jatahy, Etat de Goyaz, Brésil. Annales de la Société Entomologique de France 80: 1-150.

Linsley, E. G. \& Chemsak, J. A. 1971. An attempt to clarify the generic status of some Neotropical species currently assigned to Euryptera, Chontalia and Ophistomis (Coleoptera, Cerambycidae). Arquivos de Zoologia 21: 1-40.

Melzer, J. 1926. Longicórneos (Col.) do Brasil, novos ou pouco conhecidos. Publicações do Museu Nacional 7: 1-15.

Monné, M. A. 1995. Catalogue of the Cerambycidae (Coleoptera) of the Western Hemisphere. Part XXI. Subfamily Lepturinae. São Paulo, Sociedade Brasileira de Entomologia, $159 \mathrm{p}$.

Monné, M. A., Monné, M. L. \& Martins, U. R. 2004. Notas sinonímicas em Lepturini sul-americanos (Coleoptera, Cerambycidae, Lepturinae). Revista Brasileira de Entomologia 48: 433-438, 18 figs.

Pascoe, F. P. 1860. Notices of new or little-known genera and species of Coleoptera. The Journal of Entomology 1: 36-64.

Tavakilian, G. L. 1996. In Hequet, V., Longicornes de Guyane. Cayenne, ORSTOM, col. pls 1-19.

Villiers, A. 1980. Coléoptères Cerambycidae des Antilles françaises. I. Parandrinae, Prioninae, Lepturinae. Annales de la Société Entomologique de France 16: 133-157, 22 figs.

Zikán, W. \& Wygodzinsky, P. 1948. Catálogo dos tipos de insetos do Instituto de Ecologia e Experimentação Agrícolas. Boletim do Serviço de Pesquisas Agronómicas 4: 1-93. 